\begin{tabular}{ll}
\hline & Jurnal Sains Materi Indonesia \\
Homepage: http://jusami.batan.go.id & $\begin{array}{l}\text { Akreditation No : 21/E/KPT/2018 } \\
\text { Date 9 July 2018 } \\
\text { ISSN 1411-1098 } \\
\text { E-ISSN 2614-087X }\end{array}$ \\
\hline
\end{tabular}

\title{
STUDY OF CERIA STABILIZED ZIRCONIA MICROSPHERES MORPHOLOGY BY SMALL-ANGLE SCATTERING AND MICROSCOPY
}

\author{
Andon Insani ${ }^{1}$, Arum Patriati ${ }^{1}$, Nadi Suparno ${ }^{1}$, Ratih Langenati ${ }^{2}$, \\ Siriwat Soontaranoon ${ }^{3}$, Ridwan $^{1}$ \\ ${ }^{1}$ Center for Science and Advanced Material Technology, BATAN, Serpong, Indonesia \\ ${ }^{2}$ Center for Nuclear Fuel Technology, BATAN, Serpong, Indonesia \\ ${ }^{3}$ Synchrotron Light Research Institute (SLRI), Thailand
}

Email:andon@batan.go.id

Received: 8 October 2018

Revised: 12 December 2018

Accepted: 19 December 2018

\begin{abstract}
STUDY OF CERIA STABILIZED ZIRCONIA MICROSPHERES MORPHOLOGY BY SMALL-ANGLE SCATTERING AND MICROSCOPY. Ceria stabilized zirconia microspheres of about 500 microns were prepared by external gelation. The morphology in nano and micro scale of the microsphere was evaluated. The nanostructure of CSZ microsphere after drying was studied by small angle neutron and x-ray scattering (SANS and SAXS). In this state, the existing of the mixture of ceria oxide and zirconia oxide was observed inside the polymer matrix. The roundness and surface properties of the CSZ microsphere were observed under the optical microscopy (OM) and scanning electron microscopy (SEM). The data showed their good size uniformity, smooth surface, but also the imperfect phase of the gelation.
\end{abstract}

Keywords: microspheres, neutron scattering technique, nanostructure

\begin{abstract}
ABSTRAK
KAJIAN MORFOLOGI CERIA STABILIZED ZIRCONIA MICROSPHERES DENGAN HAMBURAN SUDUT KECIL DAN MIKROSKOPI. Ceria stabilized zirconia (CSZ) microspheres telah disintesis melalui proses gelasi eksternal yang menghasilkan microsheres berdimensi sekitar 500 mikro meter. Evaluasi terhadap struktur nano dan mikro terhadap microsheres ini telah dilakukan. Pengkajian struktur nano CSZ dilakukan menggunakan teknik hamburan sudut kecil, baik neutron maupun sinar-X (SANS dan SAXS). Pada tahap ini oksida cerium dan oksida zirkonium diketahui berada di dalam matriks polimer CSZ. Selanjutnya, struktur mikro CSZ yang berupa nilai kebulatan diamati menggunakan mikroskop optik dan scanning electron microscopy (SEM). Hasil pengamatan menunjukkan bahwa microspheres CSZ memiliki ukuran yang seragam (monodisperse), permukaan yang licin, namun di dalamnya terdapat fase gelasi yang kurang sempurna.
\end{abstract}

Keywords: Microspheres, Neutron scattering technique, Nanostructure

\section{INTRODUCTION}

Stabilized zirconia-based microsphere materials has good properties of high mechanical strength, high thermal resistance that has been used as nuclear analogous materials, one of those is ceria stabilized zirconia (CSZ) [1]. For utilization of nuclear fuels, stabilized zirconia has advantages such as high melting temperature, chemical stability, low neutron capture crosssection and stability under irradiation [2].

The main problem appears to be the formation of cracks during the thermal treatment of kernels. The crack of the kernels during thermal treatment was claimed to be preventable by vacuuming the rotary flask during drying process [3]. However, this method did not always work successfully.
In the present study, we focus on the evaluation of the CSZ microspheres by characterization of their morphology in nano and micro scale. For nano scale study, the SAS technique was applied to explore the nanostructure of a material. It was a powerful technique that allows sample analysis in in-situ experiment. The main different of small angle neutron scattering (SANS) and small angle $\mathrm{X}$-ray scattering (SAXS) is the source of the radiation beam. SANS use neutron as the radiation beam, therefore in SANS the radiation beam will interact with the nuclei and the contrast is the different of isotope scattering length density. Meanwhile, in SAXS, the radiation source is X-ray so that the contrast is the different of the electron density. Meanwhile, for micro scale study, the microscopy was used to 
observe the microstructure of a material. The optical microscopy (OM) and scanning electron microscopy (SEM) were used to evaluate the roundness and microstructure feature of CSZ microspheres. The characterization of CSZ by small angle scattering (SAS) and microscopy were performed and discussed in here.

\section{EXPERIMENTAL METHOD}

The synthesis of the CSZ microspheres studied in this work is presented on other paper [4]. The schematic diagram of the process flow for preparation of CSZ microspheres is shown in figure 1.

\section{Small Angle Scattering}

In general, the elastic scattering of a radiation beam which is passed through of some amount of sample volume provides information about sample density. The scattered radiation is recorded on a detector. The intensity and position of the scattered radiation contain structural information of the sample. The scattering pattern is normally described by intensity (I) as a function of the amplitude of the scattering vector or momentum transfer,

$q=\frac{4 \pi \sin \theta}{\lambda}$

Where $\lambda$ is the wavelength of the incident radiation, and $\theta$ is half the angle between the incident and scattered radiation. As $\lambda$ is fixed and $\theta$ is small, $I(q)$ versus $q$ is essentially the intensity as a function of scattering angle. The relationship between a scattering particle and its contribution to the scattering profile can be mathematically expressed as follows:

$I(q)=\left\langle\int\left|\left(\rho(\vec{r})-\overline{\rho_{s}}\right) e^{i \vec{q} \cdot \vec{r}} d \vec{r}\right|^{2}\right\rangle$

Where \langle\rangle refers to the rotational average and $(\rho(\vec{r})-$ $\left.\overline{\rho_{s}}\right)$ is the difference in scattering densitybetween the volume element at position $\vec{r}$ within the scattering particle and that of the solvent. The mean difference between the particle and solvent scattering density is termed the "contrast" and is usually represented as $\Delta \rho$ [5].

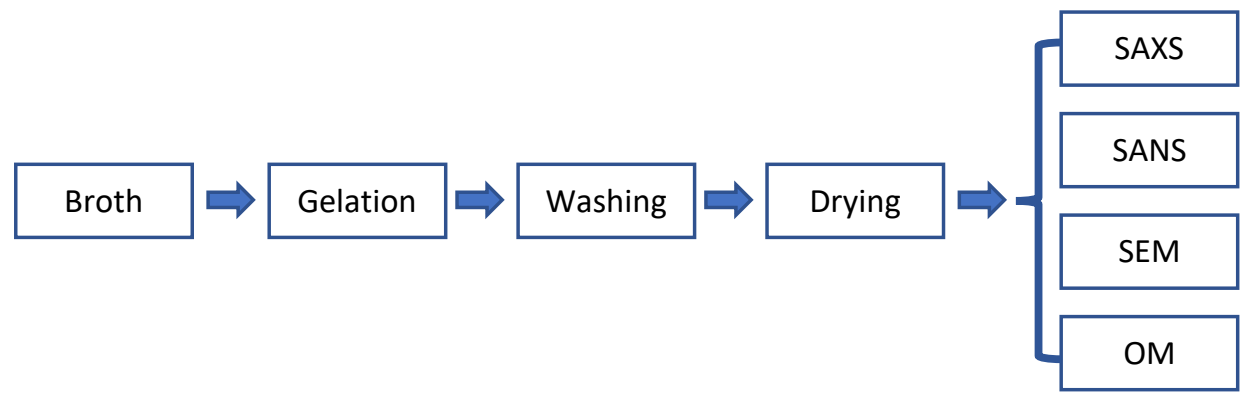

Figure 1. The schematic diagram of the process flow for preparation of CSZ microspheres

SANS experiment was conducted with SANS instrument in BATAN, Indonesia [6]. The experiment was carried out in five different settings or detector positions, i.e. $1.5 \mathrm{~m}, 3 \mathrm{~m}, 6,13$, and $18 \mathrm{~m}$. These configurations cover q range from 0.004 to $0.3 \AA^{-1}$. Each data from different setting was reduce by background scattering data using GRAsP [7]. Meanwhile, SAXS experiment was conducted at BL. 3 in SLRI, Thailand. To achieve the minimum q, the experiment was carried out at detector position $4500 \mathrm{~mm}$. This setting was followed by experiment at detector position $800 \mathrm{~mm}$ to obtain $\mathrm{q}$ range $0.007 \AA^{-1}$ to $0.4 \AA^{-1}$. The data reduction was done by using SAXSIT program, developed by SLRI [8]. The final data for both SANS and SAXS were then analyzed by Igor SANS Analysis program from NIST [9].

\section{Microscopy}

The OM and SEM measurement were carried out with Olympus BX 51 and Jeol JSM 6510 LA in BATAN, Indonesia. The sample for optical microscopy were placed on glass. The light was used to make a good image with $50 \times$ and $100 \times$ magnification. The observation using SEM was taken with $100 \times$ magnification.

\section{RESULTS AND DISCUSSION}

The nanostructure of CSZ microsphere from data from SAXS in figure 2 shows that inside the microsphere, there are many of small particles with diameter around $1.5 \mathrm{~nm}$. These small particles are distributed in matrix of the CSZ microsphere. Although the polydispersity of these small particle is large, i.e. 0.5, the existence in the CSZ microsphere matrix is dense enough. It is clearly indicating with the first hump before the upturn at $\mathrm{q}$ around $0.02 \AA^{-1}$.

The scattering profile after $\mathrm{q}$ of 0.002 shows the sharp upturn to the minimum q (look at the scattering profile from high to low $\mathrm{q}$ range). It indicates that there is a bigger particle beside the small particle. In small angle scattering, this scattering profile means that the microspheres consist of smaller particles inside the larger particle. The data analyses of the high $\mathrm{q}$ range (red line), give the information of the dimension of smaller particle diameter around $1.5 \mathrm{~nm}$. However, the information of the larger dimension cannot be gained from this scattering profile. It is due to the scattering profile in low q (green line) is continuously go up with no indication to turn flat. 


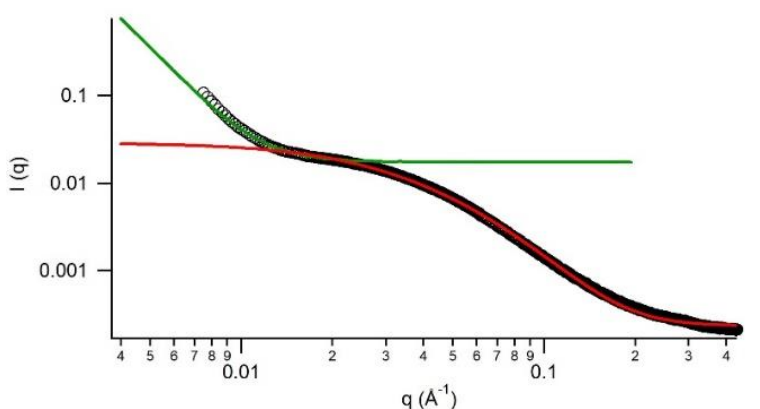

Figure 2. SAXS profile of CSZ microsphere. Black circle is the experimental data, red line is the fitting result of the high q range, and green line is the fitting result of the low q range.

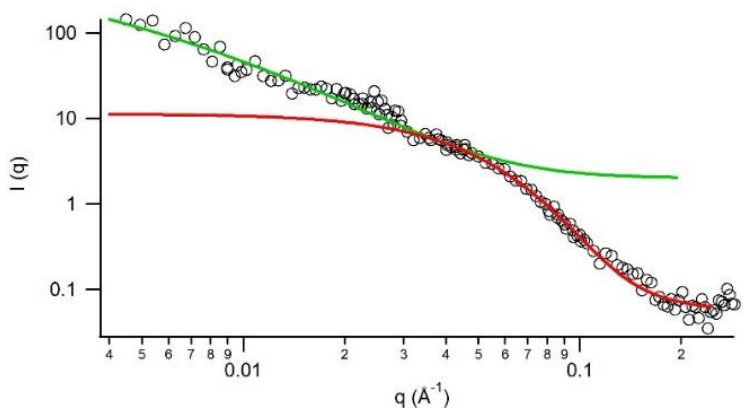

Figure 3. SANS profile of CSZ microsphere. Black circle is the experimental data, red line is the fitting result of the high q range, and green line is the fitting result of the low q range

Similar scattering profile is shown by the scattering data from SANS in figure 3 . There are two dimensions of the particle inside the microsphere. However, SANS data shows the bigger dimension compared to SAXS result. The diameter of the smaller particle, obtained from SANS, is $12 \mathrm{~nm}$. These different results are not contrast for each other, yet they complement each other.

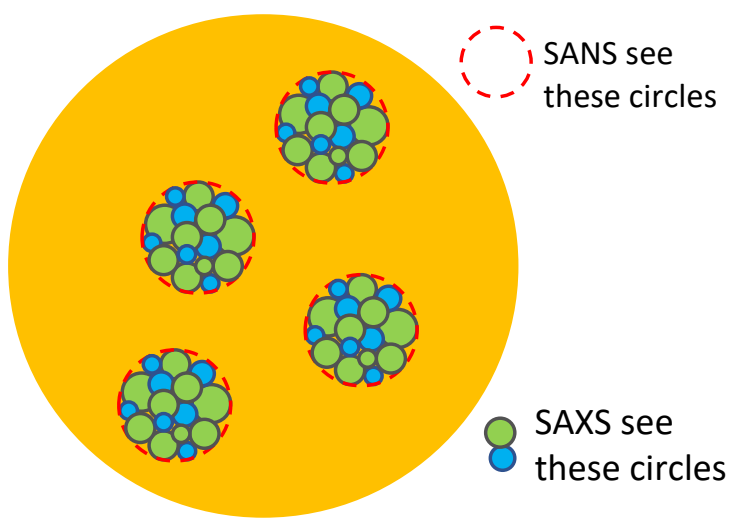

Figure 4. The illustration of the nanostructure of CSZ microsphere

X-ray and neutron have different type of interaction with matter. X-ray will interact with electron density while neutron interacts with nuclei. It means that the scattering cross section of $\mathrm{x}$-ray is in line with the atomic number of nuclei. Meanwhile the scattering cross section value of neutron is random for any nuclei. The other work about CSZ microspheres previously reports the zirconium oxide and the cerium oxide was mixed in broth solution [10]. Even though, during calcinations process, the cerium atom seems to stabilize the zirconium oxide crystal [11].

Cerium has higher atomic number, 58, than zirconium, only 40. However, cerium has lower neutron coherent scattering length compared to zirconium, 4.84 barn and 7.16 barn respectively [12]. It seems that SAXS observed each of cerium oxide and zirconium oxide differently. Therefore, the dimensions of small particles with polydispersity are observed. In other hand, SANS sees the whole mixture of cerium oxide and zirconium oxide as the coherent scattering length of both nuclei are not have high contrast.

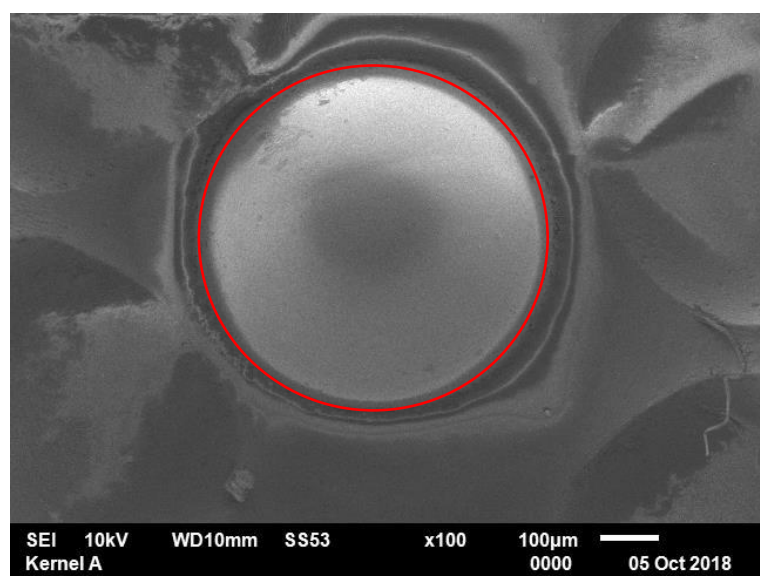

Figure 5. SEM image of CSZ microspheres

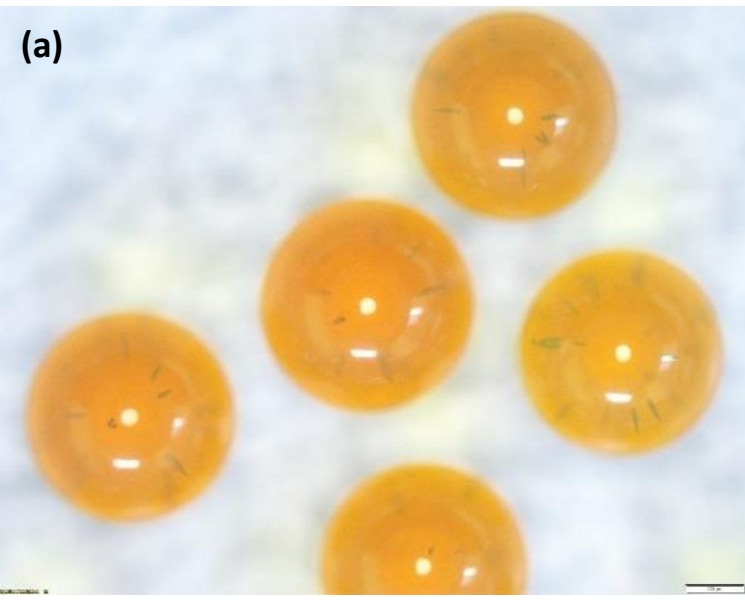

(b)

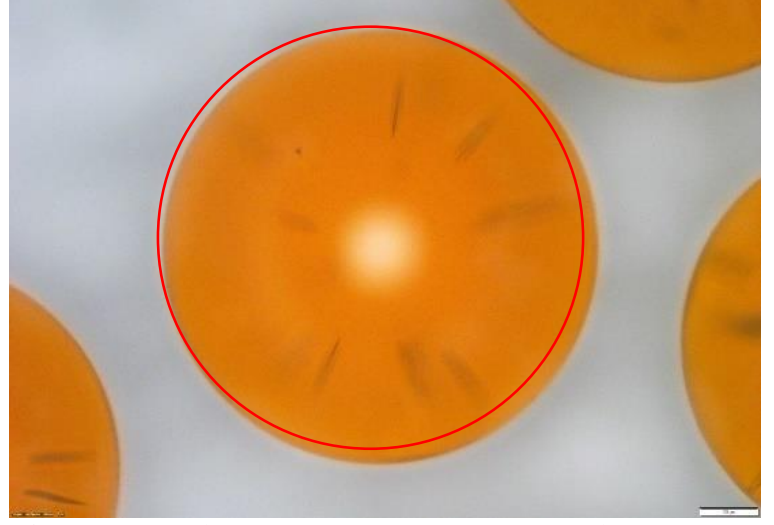

Figure 6. Optical microscopy image of CSZ microspheres 
The microstructure of the CSZ microspheres is provided by microscopy data. The SEM image in figure 5 shows that the CSZ microspheres have smooth surface with no crack. The CSZ microspheres seem to have good sphericity and $\sim 500 \mu \mathrm{m}$ diameter size. The sphericity of the CSZ microspheres here is $\sim 1.006$ which fulfill the requirement of HTGR fuel kernel specification that should be less than 1.2 [13].

The good sphericity of the CSZ microspheres is also confirmed by optical microscopy image in figure 6. Despite the shinny smooth surface shown in the optical microscopy image, there is some different phase on CSZ microsphere shown by dark color inside the sphere. Figure $6 \mathrm{~b}$ is a magnified image of figure $6 \mathrm{a}$ that clearly shows the incomplete gelation process of the CSZ microsphere during the synthesis. This incomplete state inside the CSZ microsphere is potentially the cause of the crack of the CSZ microsphere on calcinations-sintering process.

\section{CONCLUSIONS}

The small angle scattering analysis, both neutron and $\mathrm{x}$ ray, can reveal the nanostructure of CSZ nanoparticle. The mixture of zirconium oxide and cerium oxide were all still exist in this state of CSZ microsphere. The microscopy analysis conducted in this work can clarify that the synthesis path of CSZ microspheres reported in this paper can produce the microspheres with good sphericity and smooth surface. However, there is potentially incomplete gelation that should be avoided and noticed.

\section{REFERENCES}

[1] T. Arima, K. Idemitsu, K. Yamahira, S. Torikai, and Y. Inagaki, "Application of internal gelation to sol-gel synthesis of ceria-doped zirconia microspheres as nuclear fuel analogous materials," J. Alloys Compd., vol. 394, no. 1-2, pp. 271-276, 2005.

[2] G. Benay, F. Hubert, and G. Modolo, "Preparation of yttria-stabilized zirconia-ceria kernels as fuel precursors using internal gelation," Radiochim. Acta, vol. 96, no. 4-5, pp. 285-291, 2008.

[3] R. Sukarsono, M. Rachmawati, S. R. Susilowati, D. Husnurrofiq, K. Nurwidyaningrum, and A. K.
Dewi, "Effect of Sol Concentration, Aging and Drying Process on Cerium Stabilization Zirconium Gel Produced by External Gelation," J. Phys. Conf. Ser., vol. 962, no. 1, 2018.

[4] Sarjono, G. Rahmadi, E. Yusnitha, and Sukarsono, "Preparasi Kernel $\mathrm{CeO}_{2}$-Stabilized $\mathrm{ZrO}_{2}$ Tersinter sebagai Material Analog Kernel $\mathrm{UO}_{2}$, Prosiding Hasil-hasil Penelitian EBN, pp. 1-15, 2017.

[5] D. a. Jacques and J. Trewhella, "Small-angle scattering for structural biology - Expanding the frontier while avoiding the pitfalls," Protein Sci., vol. 19, no. 4, pp. 642-657, 2010.

[6] E. G. R. Putra, Bharoto, and B. S. Seong, "Recent Development of a 36 meter SmallAngle Neutron Scattering BATAN Spectrometer ( SMARTer) in Serpong Indonesia," J. Phys. Conf. Ser., vol. 012010, no. 247, pp. 1-7, 2010.

[7] C. Dewhurst, "GRASP User Manual," Tech. Rep. No. ILLO3DE01T, 2003.

[8] S. Soontaranon and S. Rugmai, "Small Angle Xray Scattering at Siam Photon Laboratory," Chinese J. Phys., vol. 50, no. 2, pp. 204-210, 2012.

[9] S. R. Kline, "Reduction and analysis of SANS and USANS data using IGOR Pro," J. Appl. Crystallogr., vol. 39, no. 6, pp. 895-900, 2006.

[10] W. Guogao, M. Jingtao, G. Yong, Z. Xingyu, H. Shaochang, and D. Changsheng, "Precisely Controlling Preparation of Ceria-Stabilized Zirconia Microspheres of $\sim 100 \mu \mathrm{m}$ by External Gelation," Int. J. Appl. Ceram. Technol., vol. 13, no. 5, pp. 831-837, 2016.

[11] A. P. Bechepeche, O. Treu, E. Longo, C. O. Paiva-Santos, and J. A. Varela, "Experimental and theoretical aspects of the stabilization of zirconia," J. Mater. Sci., vol. 34, pp. 2751-2756, 1999.

[12] L. Koester, "Neutron Scattering Lengths : A Survey of Experimental Data and Methods," At. Data Nucl. Data Tables, vol. 49, no. 1, pp. 65120, 1991.

[13] C. Tang, Y. Tang, J. Zhu, X. Qiu, J. Li, and S. $\mathrm{Xu}$, "Research and development of fuel element for chinese $10 \mathrm{MW}$ high temperature gas-cooled reactor," J. Nucl. Sci. Technol., vol. 37, no. 9, pp. 802-806, 2000. 